\title{
INCREASING TEACHERS' ABILITY IN COMPILING LESSON PLAN BASED ON STRENGTHENING CHARACTER EDUCATION THROUGH THE WORKSHOP AT SMP N 1 BATU HAMPAR, BANTAYAN, KABUPATEN ROKAN HILIR
}

\section{Lasmani}

\author{
SMP Negeri 1 Batu Hampar
}

\begin{abstract}
This school action research aims to determine whether teachers' ability in compiling the lesson plan based on Strengthening Character Education can be increased through the workshop. This study uses a model developed by Chemish and Taggart noting every action or cycle always consists of four activities: (1) the action plan, (2) action, (3) observation, and (4) reflection. As preliminary data (before the workshop), the average score of teacher's ability was $73 \%$ with good category. Having held the workshop in the first cycle, the average score obtained is $98 \%$ with very good category. The research concludes that the workshop can increase the teachers' ability in compiling the lesson plan (RPP) based PPK (Strengthening Character Education) at SMP Negeri 1 Batu Hampar.
\end{abstract}

Keywords: RPP, PPK, Workshop

\section{Introduction}

The curriculum is a system of learning programs to achieve the goal of institutional at educational institutions, so that curricula play an important role in realizing a quality school. The curriculum is also one of the aspects that affect the success of national education.

The mouth of the actual curriculum success will be determined by the implementation of the curriculum. Infact, there are mismatch between the implementation of the curriculumwith the learning design,therefore resulting inaccessibility objectives that have been set.In ordet to adjust between the curriculum with the learning design, it takes some preparations, especially the readiness of the executor. Whatever the learning design or the curriculum design, its success depends on the teacher. The teacher is the key of success of an education.

Referring to the above, teachers are expected to be able to prepare for learning, whether it concerns learning material as well as the psychological 
and psychic conditions conducive to the ongoing learning process.Learning should ideally be planned, implemented, and assessed by a teacher and overseen by the principal.

Based on the teachers' information it can be concluded that the teacher still feel confused in formulating the RPP (Lesson Plan). The first reason is the frequent changes in curriculum. Since 2004, there have been 4 changes, namely from KTSP, KBK, 13th edition of Curriculum and curriculum Revision 13, 2016 and 2017. The second reason, there are teachers who teach different lessons with his educational background. Therefore, some of them compile the Lesson Plan usually copy-paste of the MGMP or buy a learning device available.

To resolve the issue listed above then it is necessary to provide guidance to all teachers in compiling lesson plan based on Strengthening Character Education. So that teachers can compile lesson plan based on Strengthening Character Education properly in accordance with applicable guidelines, namely Minister of Education and Culture No.22 of 2016. This research aims to determine whether teachers' ability in compiling the lesson plan based on Strengthening Character Education can be increased through the workshop.

\section{Review of the Literature}

Lesson Plan also known as instructional design is the initial activities that must be done before teachers implement the learning process. The design is a pattern or a model (Rusman, 2008:24). Designing learning means drafting or drawing up a learning model in accordance with the syllabus, core competence and basic competence required. Teachers are expected to also afford lays out the objectives stated in the curriculum into goals that are more specific. Furthermore, the specific objectives are translated into learning activities. The activity before the implementation of learning is called planning activities.

Planning is also said to be the selection of a number of alternatives regarding the establishment of procedures for achievement, as well as estimates of the sources that can be provided to achieve these objectives (Soetjipto, 2004:134). Planning is a set of operations that is consistent and coordinated in order to obtain the desired results (Oemar Hamalik, 2008:135). While teaching or teaching unit is a form of preparation in detail per basic competencies are organized systematically.

Meanwhile Wahjosumidjo in his book "Kepemimpinan Kepala Sekolah Tinjauan Teoretik dan Permasalahannya"write that what is meant by the teaching program is as subject matter, time allotment, and distribution in each class and education unit (2007:209). Other limitations of RPP contained in the Regulation of the Minister of Education and Culture No. 22 Year 2016 stated that the RPP is a learning activity plan created for one or more meetings and is a translation of the syllabus describing procedures and organizing learning to achieve basic competencies set out in the Standard 
Content. RPP were used as guidelines for teachers in implementing the learning in the classroom, laboratory, and/or field. From this limit can be concluded that the planning of learning or teaching program is a determination procedure or guesses made by the teacher in the learning preparation for composing competencies particular on certain subjects in order to obtain the desired results.

The format of the RPP can be developed according to the Regulation of the Minister of Education and Culture No. 22 Year 2016 are as follows:

\section{THE PLAN OF IMPLEMENTATION OF THE LEARNING}

$\begin{array}{ll}\text { School } & : \ldots \ldots \ldots \ldots \ldots \ldots \\ \text { Subjects } & : \ldots \ldots \ldots \ldots \ldots \ldots \\ \text { Class/Semester } & : \ldots \ldots \ldots \ldots \ldots \ldots \ldots \\ \text { Allocation of time } & \ldots \ldots \ldots \ldots \ldots \ldots \ldots\end{array}$

A`Core Competence

B. The Basic Competencies and Indicators of Achievement of the Competencies, Character-Focus

C. Learning Objectives

D. Learning Material

- Regular Material

- Remedial Material

- Enrichment Materials

E. Learning Methods

F.Learning Resources

G. Learning Steps

1. Preliminary activities

2. Core Activity

3. Closing Activity

H. Assessment

- Valuations Stance:

1. Spiritual Attitude
2. Social Attitude

- Assessment Knowledge

- Assessment Skills

And teachers are expected to integrate the strengthening character education (PPK) in learning. The character of mainly reinforced 5 characters, namely religious, nationalist, self help, mutual, and integrity.

The strengthening character education (PPK) movement needs to integrate, deepen, expand, and simultaneously harmonize various character education programs and activities that have been carried out until now. In this connection integration can take the form of integrating class activities, outside the classroom at school, and outside the school (community/community); integration of intracurric, co-curricular and extracurricular activities; simultaneous involvement of school, family and community citizens; deepening and expansion can be in the form of additions and intensification of activities oriented to the development of student character, addition and sharpening of student learning activities, and rearrangement of student learning time at school or outside school; then it can be in the form of adjusting the main tasks of the teacher, School Based Management, and the functions of the School Committee with the needs of the strengthening character education (PPK) Movement..

In order for teachers to have the ability to prepare lesson plan based on Strengthening Character Education that are in accordance with the guidelines or 
rules, a workshop is needed. The workshop according to the Big Indonesian Language Dictionary (KBBI) is a meeting to exchange knowledge and experience among a number of participants who have the same expertise or profession, in order to increase knowledge or solve a problem.

Workshop, namely activities which in the event there are people who have expertise in a particular field, assembled and then discuss specific issues and give teaching/training to the participants. It can be said also workshop is providing teaching/training to the participants, regarding the theory and also practice on a field. Or in other words a workshop namely exercise for participants who work for individuals or groups to resolve issues related to the actual task work/with a view to gaining an experience.

Based on the background and literature review above, it can be formulated a research that workshop can increase the ability of SMP N 1 Batu Hampar's teachers in compiling the lesson plan (RPP) based PPK (Strengthening Character Education).

\section{Research Methodology}

This research is an action research. Carr and Kemmis in Mc Niff (1992) suggested that action research is a natural reflection done by partisipants, teachers, and students to increase practical aspects.

This workshop is useful for solving teacher problems in compiling lesson plans. There are 4 activities in this study, namely planning, implementation, observation and reflection in one cycle. If this problem is not resolved in the first cycle, it will be continued in cycle II with some revisions therein. The action activities in this study can be seen as follows:

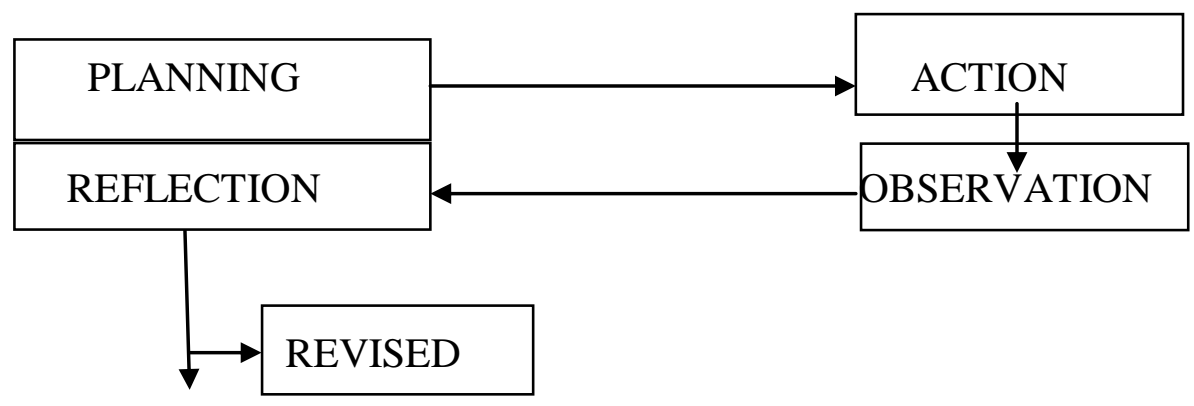

Figure 1: Action Research

The subjects of this research are all of the teachers of SMP N 1 Hampar, 13 female teachers and 4 male teachers. This workshop was held on November 13, 2018 - December 20, 2018. This study uses a model developed by
Chemish and Taggart noting every action or cycle always consists of four activities: (1) the action plan, (2) action, (3) observation, and (4) reflection. To obtain an accurate data, beside using the initial assessment instrument, the 
researcher also uses he format of the lesson plan in the Regulation of the Minister of Education and Culture No. 22 Year 2016.

To provide an assesssment of the success of each cycle of action, the researcher needs indicators of success. This research is categorized success if each activity get the following classification :
1. Classification is very good for aspects of organizing workshop activities.

2. Classification is very good for the activities of participants in the workshop.

3. Classification is very good for aspects of compiling lesson plans by participants in the workshop.

The interval for classification can be seen in the following table:

Table 1. Interval Analysis

\begin{tabular}{|c|l|c|}
\hline NO & \multicolumn{1}{|c|}{ CATEGORY } & INTERVAL \\
\hline 1. & Very Good & $80-100$ \\
\hline 2. & Good & $60-79$ \\
\hline 3. & Enough & $50-59$ \\
\hline 4. & Less & $0-49$ \\
\hline
\end{tabular}

The Description of research activities on each cycle can be seen in the following:

\section{Planning}

a. Socialize the plan for the implementation of the workshop;

b. Making monitoring and evaluation instruments;

c. Coordinate workshop plans for all parties that will be involved such as school supervisors, resource persons, observers, etc ;

d. Motivating all school residents involved in the workshop.

\section{Implementation}

Collect Lesson Plans (RPP), namely:

1. RPP collected during the supervision class in October 2018. This was used as the background of teacher's ability in drawing up the RPP.

2. RPP collected after the implemented workshops. RPP this is analyzed and used as the end result.

\section{Observation}

In this stage the observation sheet is used for analysis. There are 2 observation sheets, namely aspects of organizing workshop activities and aspects of the activities of participants in the workshop activities.

The observation sheet is used to determine developments and identify whether activities are in accordance with planning. 


\section{Reflection}

This stage includes the process of analyzing the results of activities, and preparing a plan for improvement, if there are weaknesses or shortcomings, for further activities.

\section{Result and Discussion}

To find out whether teachers' ability in compiling the lesson plan based on Strengthening Character Education can be increased through the workshop, the researcher compares the lesson plan that collected before the workshop (pre-cycle) and after the workshop (cycle I). We can see the table figured below :

Tabel 2. Teacher's Ability Compoling Lesson Plan Based on Strengthening Character Education

\begin{tabular}{|c|c|c|c|}
\hline \multirow[b]{2}{*}{$\begin{array}{c}\text { No } \\
\cdot\end{array}$} & \multirow[t]{2}{*}{ The Format of Lesson Plan } & \multicolumn{2}{|c|}{ The Percentage } \\
\hline & & $\begin{array}{c}\text { Before } \\
\text { The } \\
\text { Workshop } \\
\text { (Pre - } \\
\text { Cycle) }\end{array}$ & Cycle I \\
\hline 1 & Sort the components of the RPP & $67 \%$ & $100 \%$ \\
\hline 2 & Specify The Identity Of The RPP & $100 \%$ & $100 \%$ \\
\hline 3 & Define The Core Competencies & $71 \%$ & $100 \%$ \\
\hline 4 & Determine The Basic Competence & $100 \%$ & $100 \%$ \\
\hline 5 & $\begin{array}{l}\text { Devise Indicators Of Achievement Of The } \\
\text { Competencies }\end{array}$ & $53 \%$ & $84 \%$ \\
\hline 6 & $\begin{array}{l}\text { Adjust the Focus characters with Basic } \\
\text { Competencies }\end{array}$ & $53 \%$ & $100 \%$ \\
\hline 7 & Define Learning Objectives & $67 \%$ & $88 \%$ \\
\hline 8 & $\begin{array}{l}\text { Lists Regular Learning Materials, } \\
\text { Enrichment and Remedial }\end{array}$ & $33 \%$ & $100 \%$ \\
\hline 9 & Customize Learning Methods & $100 \%$ & $100 \%$ \\
\hline 10 & $\begin{array}{l}\text { Determine which Media and learning } \\
\text { materials }\end{array}$ & $67 \%$ & $100 \%$ \\
\hline 11 & Write down the complete learning resource & $100 \%$ & $100 \%$ \\
\hline 12 & Outlines The Steps Of Learning & $67 \%$ & $100 \%$ \\
\hline 13 & $\begin{array}{l}\text { Determine The Dwarf, Forms, Assessment } \\
\text { Rubric }\end{array}$ & $67 \%$ & $100 \%$ \\
\hline & The Average & $\begin{array}{c}73 \% \\
(\text { Good })\end{array}$ & $\begin{array}{l}\mathbf{9 8 \%} \\
\text { (Very } \\
\text { Good) }\end{array}$ \\
\hline
\end{tabular}

Source: Processed Research 
From the data research, we can conclude that before having the workshop activity, the teachers' ability in compiling the lesson plan based on Strengthening Character Education is stil low. The teachers have low competence in devise indicators of achievement of the competencies, adjust the focus characters with basic competencies, lists regular learning materials, enrichment and remedial according to the Regulation of the Minister of Education and Culture No. 22 Year 2016. Based on the condition, then the researcher held a research in order to increase the teachers' ability in compiling the lesson plan based on Strengthening Character Education.
After having held the workshop, there is a significant increasing toward the teacher's ability in compiling the lesson plan based on Strengthening Character Education. The percentage in pre-cycle is $73 \%$ become $98 \%$ in Cycle I. In fact, most of the teacher of SMP N 1 Batu Hampar has understood how to compile the lesson plan based on strengthening character education exactly, because they have ever got training before. So, after being given the workshop, it is easy for them to understand it. It can be conclude that the teacher's ability in compiling the lesson plan based on Strengthening Character Education can be increased through workshop. It can be seen from the graph below :

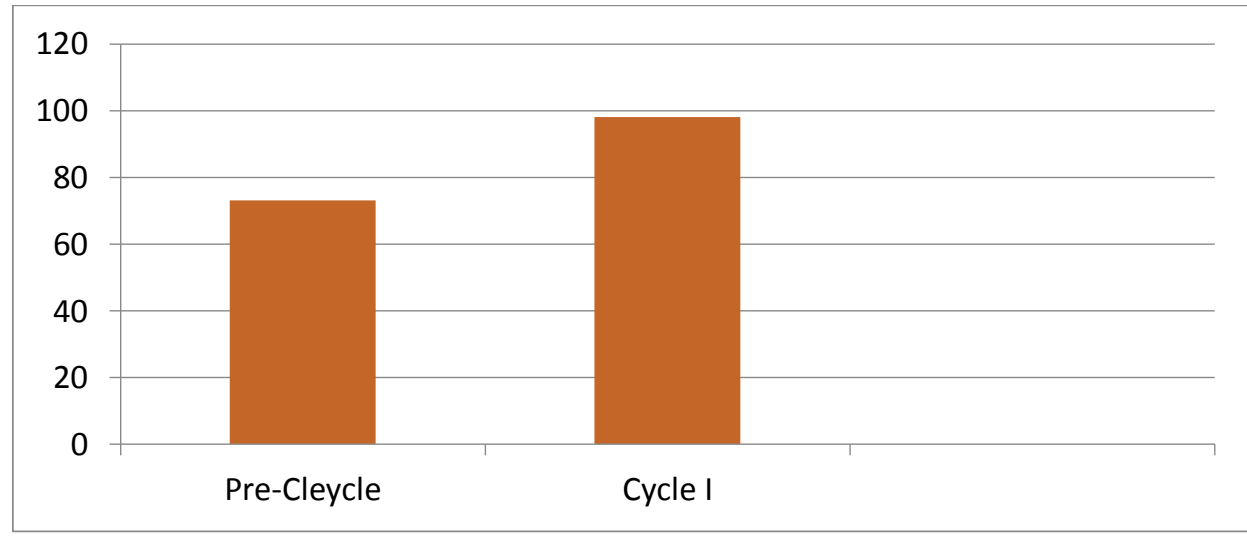

Graph 1

\section{Conclussion and Suggestion}

From this action research activity, it can be concluded that an effort increasing the teachers' ability in compiling the lesson plan based on Strengthening Character Education, it can be done with activities in the form of workshops. It is suggested for teachers who have followed training changes or the establishment of the curriculum, in order to convey the knowledge that has been gained from training, so that other teachers get the same thing.

\section{LITERATURE}

Depdikbud. 2016. Peraturan Menteri Pendidikan dan Kebudayaan Nomor 22 Tahun 2016, tentang 
Standar Proses. Jakarta:

Depdikbud.

Hamalik, Oemar. 2008. Manajemen

Pengembangan Kurikulum.

Bandung: PT. Remaja Rosda

Karya.

Departemen Pendidikan Nasional.

(2008). Kamus Besar Bahasa

Indonesia. Edisi Keempat.

Jakarta:Balai Pustaka

Kemendiknas. 2010. Penelitian

Tindakan Sekolah Materi

Pelatihan Penguatan

Kemampuan Kepala

Sekolah. Jakarta: Dirjen

PMPTK.

Manulang, 2005. Dasar-dasar

Manajemen. Jogjakarta: Gadjah

Mada University Press.

Rusman. 2008. Manajemen Kurikulum

Seri manajemen Sekolah Bermutu.

Bandung: Mulia Mandiri Press.

Soetjipto dan Kosasi. 2004. Profesi

Keguruan. Jakarta: PT Rineka Cipta.

Wahjosumidjo. 2007. Kepemimpinan

Kepala Sekolah Tinjauan

Teoretik dan Permasalahannya.

Jakarta: PT RajaGrafindo

Persada. 